\title{
Study of extraction and chemical compounds of Scrophularia striata Boiss. and Scrophularia deserti Delile using HS-SPME and GC-MS
}

\author{
Mahmoud Bahmani ${ }^{1}$, Marzieh Hadavi², Naser Abbasi ${ }^{1 *}$ \\ ${ }^{1}$ Biotechnology and Medical Plants Research Center, Ilam University of Medical Sciences, Ilam, Iran \\ ${ }^{2}$ Department of Internal Medicine, School of Medicine, Shahid Mostafa Khomaeini Hospital, Ilam University of Medical sciences, Ilam, \\ Iran
}

\section{*Correspondence to: \\ Dr. Naser Abbasi \\ ilamfarma@gmail.com}

Received: 09 December 2020

Accepted: 10 May 2020

ePublished: 16 June 2020

Keywords: Scrophularia striata Boiss., Scrophularia deserti Delile, Essential oil, HS-SPME, GC-MS

\section{Citation:}

Bahmani M, Hadavi M, Abbasi N. Study of extraction and chemical compounds of Scrophularia striata Boiss. and Scrophularia deserti Delile using HS-SPME and GC-MS. Plant Biotechnology Persa. 2020; 2(1): 8-13

\section{bstract}

In this study, from June 2019 to May 2019 aerial parts of Scrophularia striata Boiss. were collected from Ilam city and those of Scrophularia deserti Delile from Dehloran city, Ilam province in western Iran. The aerial parts of the medicinal plants were pulverized. The essential and volatile oils were extracted by headspace solid-phase microextraction (HSSPME) and their chemical compounds analyzed by Gas chromatography-mass spectrometry (GC-MS). Using HS-SPME, 68 and 49 chemical compounds were identified from $S$. striata and $S$. deserti, respectively. Spathulenol (18.41\%) was the highest chemical compound of the essential oil of $S$. striata, followed by caryophyllene oxide (15.38\%), linalool (11.85\%), alpha-terpineol (8.34\%), trans-caryophyllene (4.44\%) and geraniol (3.10\%). The most important identified compounds from $S$. deserti were caryophyllene oxide $(15.38 \%)$, linalool $(11.85 \%)$, alpha-terpineol $(8.34 \%)$, trans-caryophyllene $(4.44 \%)$ and geraniol $(3.10 \%)$. The most important chemical compounds of $S$. deserti essential oil included alpha-pinene (25.54\%), alpha-phellandrene (19.60\%), beta-myrcene $(11.29 \%$ ) and trans-caryophyllene (6.78\%). Results show major constituents of this two plant include with a high amount of Spathulenol and caryophyllene oxide has high pharmaceutical and healthful value.

\section{Introduction}

The Scrophulariaceae family is composed of 220 genera. The genus is one of the major genera of the Scrophulariaceae family. These genera such as Scrophularia farinosa Boiss and Scrophularia amplexicaulis Benth mainly distribute in mountainous areas and are rarely found in deserts, such as Scrophularia deserti Delile. This genus has 60 species in Iran and can be used as heart stimulants, circulatory stimulants and diuretics [1]. Scrophularia deserti belonging to the Scrophulariaceae family, occurs mostly as grassy or shrubby and rarely as tree,, its leaves are alternate, crossed, simple and without earrings, its flowers are five feathers, zygomorphic, its flower cup has lobes and its fruit is usually like capsule with multiple seeds [2]. S. deseri occurs in Persian Gulf countries and also in Iran, especially in western and southern parts of the country, such as Ilam, Kermanshah, Hamadan, Khouzestan including Ahvaz, Lorestan, Bushehr, Hormozgan and Yazd [3]. S. deserti has antimicrobial, antifungal, wound healing, anti-cancer, wound cleansing, anti-diabetic, and anti-inflammatory effects. The most im- portant constituents of the plant include harpagosside $\mathrm{B}$ and scropolioside-D2 belonging to iroid glycosides $[4,5]$. S. deserti occurs mostly as grassy or shrubby and rarely as tree, its leaves are alternate, crossed, simple and without earrings, its flowers are five feathers, zygomorphic, its flower cup has lobes and its fruit is usually like capsule with multiple seeds [6]. Studies show that the plant is gastric tonic, and has traditionally been used to treat diseases such as scrofula, scabies, tumors, eczema, psoriasis and inflammatory infections, and is somehow effective against Staphylococcus aureus and Pseudomonas aeruginosa $[7,8]$.

Therefore, due to the popular use of $S$. deserti and S. striata in traditional medicine of Ilam, as part of continuous phytochemical investigations of chemical compounds, the essential oils of the two plants aerial parts were analyzed using GC-MS and HSSPME.

Copyright (C) 2020 The Author(s). This is an open-access article distributed under the terms of the Creative Commons Attribution License (http://creativecommons.org/licenses/by/4.0), which permits unrestricted use, distribution, and reproduction in any medium, provided the original work is properly cited. 


\section{Materials and methods}

\section{Plant preparation}

S. striata samples were collected from Ilam in June 2019 and S. deseri samples from Dehloran in May 2019. The plant was identified and confirmed using morphological keys of Ilam Province Plant Flora Book at Ilam University of Medical Sciences Biotechnology and Medicinal Research Center. The collected plants were cleansed and shade dried in the open air.
The dried plant was pulverized by a plant mixer and analyzed by HS-SPME for chemical composition analysis. The characteristics of the medicinal plants studied are listed in Table 1.

Table 1. The details of Scrophularia striata and Scrophularia deserti

\begin{tabular}{|c|c|c|c|c|}
\hline Plant name & Scientific name & Herbal family & Collecting area & $\begin{array}{l}\text { Geographical } \\
\text { coordinates }\end{array}$ \\
\hline Organic snapper & Scrophularia striata & Scrophulariaceae & Ilam & $\begin{array}{l}32^{\circ} 41^{\prime} 28^{\prime \prime} \\
\text { North, } 47^{\circ} 15^{\prime} \\
58^{\prime \prime} \text { East }\end{array}$ \\
\hline Snapdragon desert & Scrophularia deserti & Scrophulariaceae & Dehloran & $\begin{array}{l}33^{\circ} 38^{\prime} 14.64^{\prime \prime} \\
\text { North, } 46^{\circ} 25^{\prime} \\
21.72^{\prime \prime} \text { East }\end{array}$ \\
\hline
\end{tabular}

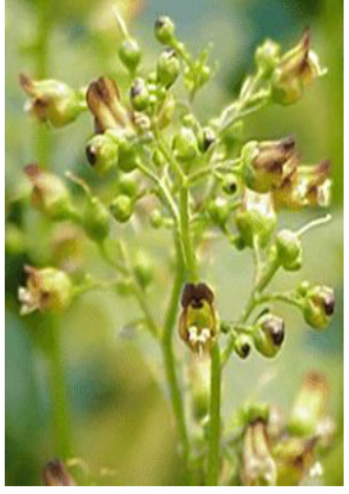

Scropularia striata

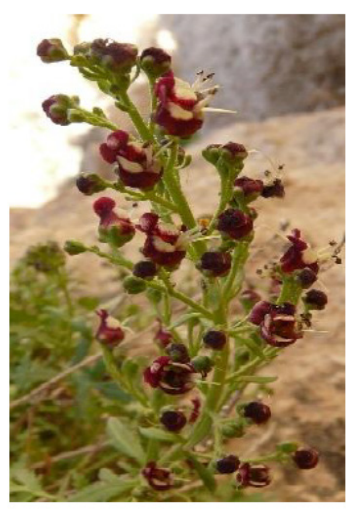

Scropularia deserti
Figure 1. Pictures of medicinal plants of Scropularia striata and Scropularia deserti

\section{Identification of compounds using HS-SPME}

In this experiment, the essential oil of the plant was extracted by HS-SPME technique. In this technique, about 2 grams of dried plant and its powder were placed in the vial and the vial temperature was set at $60-70{ }^{\circ} \mathrm{C}$. These optimum temperature conditions will saturate the vapor content of the substances in the plant essential oil in the headspace of the solid surface. The SPME syringe with a lid on it was then placed in the headspace of the container and the material in the vapor waz absorbed by the silica phase in the instrument needle. After the silica fiber was allowed to sufficiently saturate with volatile components, the fiber was directly placed into the GC/MS input section and materials present in the fiber were adsorbed due to the temperature of the input and then entered into the GC/MS apparatus for identification [9].

\section{HS-SPME Method}

$2 \mathrm{~g}$ of each plant extract was used for analysis. The device condition was as follows: Gas chromatograph (Agilent6890N) was coupled to Agilent 5973 Mass detector; Column: HP - 5. (30 m length $\times 0.25 \mathrm{~mm}(\mathrm{ID}) \times 0.25 \mu \mathrm{m}$ (stationary phase thickness); Injector type: split/splitless and column temperature program: $50 \mathrm{oC}$, hold time $0.00 \mathrm{~min}$ and rate of $-\mathrm{oC} / \mathrm{min}$; temperature
$200 \mathrm{oC}$, hold time, $0.00 \mathrm{~min}$ and rate of $5 \mathrm{oC} / \mathrm{min}$ and temperature $240^{\circ} \mathrm{C}$, hold time $0.00 \mathrm{~min}$ and rate of $10 \mathrm{oC} / \mathrm{min}$. Carrier gas: $\mathrm{He}$ (99.999\%); Injection type: splitless; Library: Wiley 7n; Injector temperature: $250^{\circ} \mathrm{C}$ and flow rate: $0.9 \mathrm{~mL} / \mathrm{min}$. Extraction mode: (HSSPME); SMPE fiber: PDMS $100 \mu \mathrm{m}$ thickness (SUPELCO); sample weight: $0.5 \mathrm{~g}$; extraction temperature: $60 \mathrm{oC}$; extraction time: $20 \mathrm{~min}$; sonication time: $10 \mathrm{~min}$ (Euronda sonication instrument, Italy) and desorption time in GC-MS injector port: 3 $\min [10]$.

\section{Results}

$2 \mathrm{~g}$ of each plant extract was used for analysis. The device condition was as follows: Gas chromatograph (Agilent6890N) was coupled to Agilent 5973 Mass detector; Column: HP - 5. (30 $\mathrm{m}$ length $\times 0.25 \mathrm{~mm}$ (ID) $\times 0.25 \mu \mathrm{m}$ (stationary phase thickness); Injector type: split/splitless and column temperature program: $50 \mathrm{oC}$, hold time $0.00 \mathrm{~min}$ and rate of $-\mathrm{oC} / \mathrm{min}$; temperature $200 \mathrm{oC}$, hold time, $0.00 \mathrm{~min}$ and rate of $5 \mathrm{oC} / \mathrm{min}$ and temperature $240^{\circ} \mathrm{C}$, hold time $0.00 \mathrm{~min}$ and rate of $10 \mathrm{oC} / \mathrm{min}$. Carrier gas: $\mathrm{He}$ (99.999\%); Injection type: splitless; Library: Wiley 7n; Injector temperature: $250^{\circ} \mathrm{C}$ and flow rate: $0.9 \mathrm{~mL} / \mathrm{min}$. Extraction mode: (HSSPME); SMPE fiber: PDMS $100 \mu \mathrm{m}$ thickness (SUPELCO); sample weight: $0.5 \mathrm{~g}$; extraction temperature: $60 \mathrm{oC}$; extraction time: $20 \mathrm{~min}$; sonication time: $10 \mathrm{~min}$ (Euronda sonication instrument, Italy) and desorption time in GC-MS injector port: 3 $\min [10]$.

Table 2. Identified constituents from essential oil of Scrophularia striata aerial parts using headspace solid-phase microextraction (GC-MC)

\begin{tabular}{llll}
\hline No. & $\begin{array}{l}\text { Retention } \\
\text { time }\end{array}$ & compound & $\%$ \\
\hline 1 & 4.49 & 2-Hexenal & 0.01 \\
2 & 6.15 & Alpha-thujene & 0.03 \\
3 & 6.33 & Alpha.-pinene & 0.39 \\
4 & 6.65 & Sbinene & 0.02
\end{tabular}




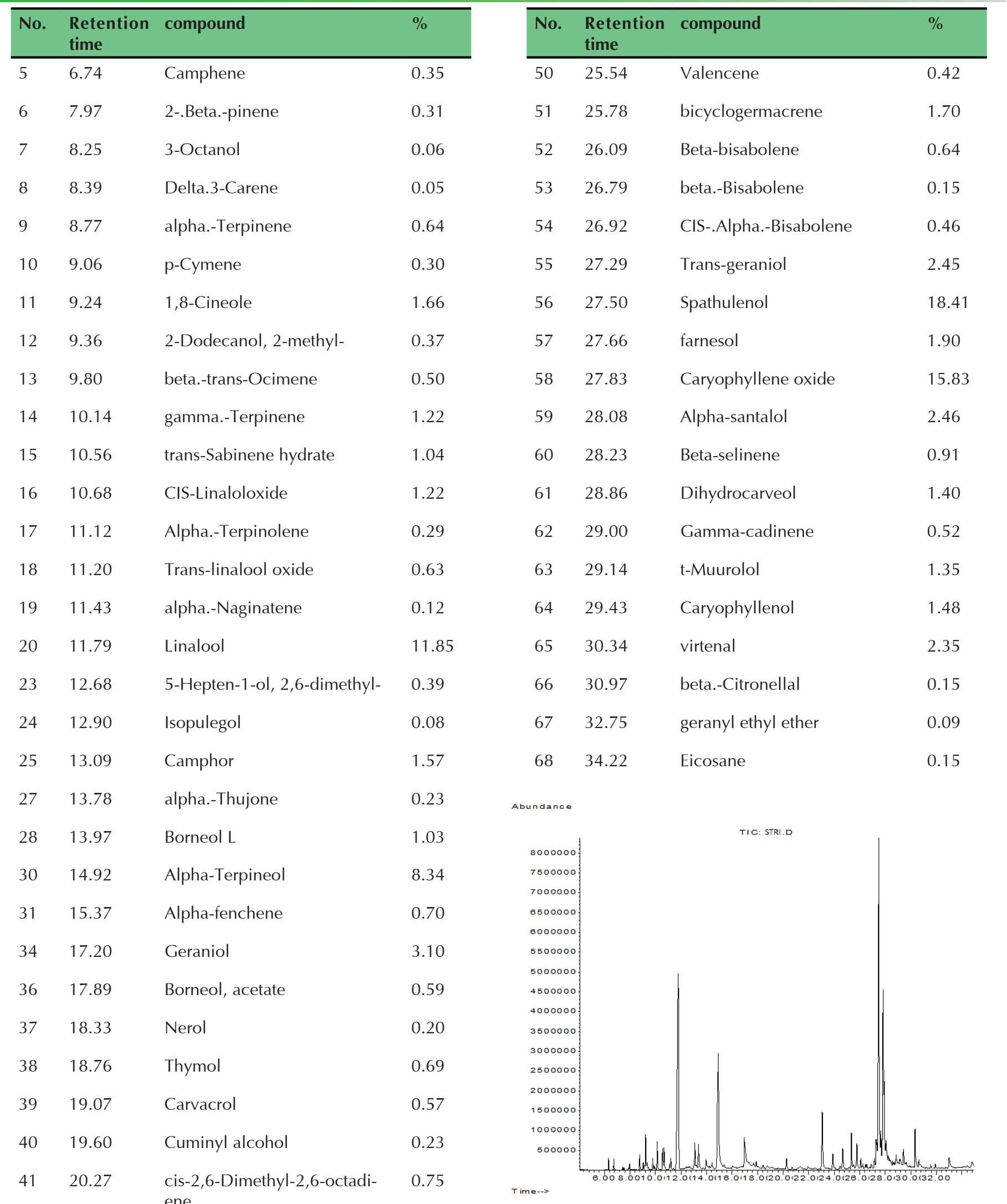

$42 \quad 20.96 \quad$ alpha.-Amorphene 0.03

Figure 1. Chromatogram of essential oil of Scrophularia striata aerial parts using headspace solid-phase microextraction (GC-MC)

According to our results, the most important chemical compounds of S. deserti essential oil include alpha-pinene (25.54\%), alpha-phellandrene (19.60\%), beta-myrcene (11.29\%) and trans-caryophyllene (6.78\%). 
Table 3. Identified constituents from essential oil of Scrophularia deserti aerial parts using headspace solid-phase microextraction (GC-MC)

\begin{tabular}{|c|c|c|c|}
\hline No. & $\begin{array}{l}\text { Retention } \\
\text { time }\end{array}$ & compound & $\%$ \\
\hline 1 & 4.49 & 2-Hexenal & 0.01 \\
\hline 2 & 6.15 & Alpha-thujene & 0.03 \\
\hline 3 & 6.33 & Alpha.-pinene & 0.39 \\
\hline 4 & 6.65 & Sbinene & 0.02 \\
\hline 5 & 6.74 & Camphene & 0.35 \\
\hline 6 & 7.97 & 2-.Beta.-pinene & 0.31 \\
\hline 7 & 8.25 & 3-Octanol & 0.06 \\
\hline 8 & 8.39 & Delta.3-Carene & 0.05 \\
\hline 9 & 8.77 & alpha.-Terpinene & 0.64 \\
\hline 10 & 9.06 & p-Cymene & 0.30 \\
\hline 11 & 9.24 & 1,8-Cineole & 1.66 \\
\hline 12 & 9.36 & 2-Dodecanol, 2-methyl- & 0.37 \\
\hline 13 & 9.80 & beta.-trans-Ocimene & 0.50 \\
\hline 14 & 10.14 & gamma.-Terpinene & 1.22 \\
\hline 15 & 10.56 & trans-Sabinene hydrate & 1.04 \\
\hline 16 & 10.68 & CIS-Linaloloxide & 1.22 \\
\hline 17 & 11.12 & Alpha.-Terpinolene & 0.29 \\
\hline 18 & 11.20 & Trans-linalool oxide & 0.63 \\
\hline 19 & 11.43 & alpha.-Naginatene & 0.12 \\
\hline 20 & 11.79 & Linalool & 11.85 \\
\hline 23 & 12.68 & 5-Hepten-1-ol, 2,6-dimethyl- & 0.39 \\
\hline 24 & 12.90 & Isopulegol & 0.08 \\
\hline 25 & 13.09 & Camphor & 1.57 \\
\hline 27 & 13.78 & alpha.-Thujone & 0.23 \\
\hline 28 & 13.97 & Borneol L & 1.03 \\
\hline 30 & 14.92 & Alpha-Terpineol & 8.34 \\
\hline 31 & 15.37 & Alpha-fenchene & 0.70 \\
\hline 34 & 17.20 & Geraniol & 3.10 \\
\hline 36 & 17.89 & Borneol, acetate & 0.59 \\
\hline 37 & 18.33 & Nerol & 0.20 \\
\hline 38 & 18.76 & Thymol & 0.69 \\
\hline 39 & 19.07 & Carvacrol & 0.57 \\
\hline
\end{tabular}

\begin{tabular}{llll}
\hline No. & $\begin{array}{l}\text { Retention } \\
\text { time }\end{array}$ & $\%$ \\
\hline 40 & 19.60 & Cuminyl alcohol & 0.23
\end{tabular}

$4120.27 \quad$ cis-2,6-Dimethyl-2,6-octadi- $\quad 0.75$ ene

$42 \quad 20.96 \quad$ alpha.-Amorphene 0.03

$\begin{array}{lll}45 & 22.54 \quad \text { alpha.-Gurjunene } & 0.22\end{array}$

$\begin{array}{lll}46 & 23.08 & \text { trans-Caryophyllene }\end{array}$

$\begin{array}{lll}48 & 23.90 & \text { Aromadendrene }\end{array}$

$49 \quad 25.35 \quad$ Germacrene-D 1.92

$\begin{array}{llll}50 & 25.54 & \text { Valencene }\end{array}$

$51 \quad 25.78 \quad$ bicyclogermacrene $\quad 1.70$

$52 \quad 26.09 \quad$ Beta-bisabolene $\quad 0.64$

$5326.79 \quad$ beta.-Bisabolene 0.15

$5426.92 \quad$ CIS-.Alpha.-Bisabolene $\quad 0.46$

$\begin{array}{lll}55 & 27.29 & \text { Trans-geraniol }\end{array}$

$\begin{array}{lll}56 & 27.50 \quad \text { Spathulenol } & 18.41\end{array}$

$\begin{array}{lll}57 & 27.66 & \text { farnesol }\end{array}$

$\begin{array}{lll}58 & 27.83 & \text { Caryophyllene oxide }\end{array}$

$\begin{array}{llll}59 & 28.08 & \text { Alpha-santalol } & 2.46\end{array}$

$\begin{array}{llll}60 & 28.23 & \text { Beta-selinene } & 0.91\end{array}$

$61 \quad 28.86 \quad$ Dihydrocarveol $\quad 1.40$

$62 \quad 29.00 \quad$ Gamma-cadinene 0.52

$\begin{array}{llll}63 & 29.14 & \mathrm{t}-\text { Muurolol } & 1.35\end{array}$

$\begin{array}{lll}64 & 29.43 & \text { Caryophyllenol }\end{array}$

$\begin{array}{llll}65 & 30.34 & \text { virtenal } & 2.35\end{array}$

$\begin{array}{lll}66 & 30.97 \quad \text { beta.-Citronellal } & 0.15\end{array}$

$\begin{array}{lll}67 & 32.75 & \text { geranyl ethyl ether }\end{array}$

$\begin{array}{llll}68 & 34.22 & \text { Eicosane } & 0.15\end{array}$

.46
.91
.40
.52
.35
.48
.35
0.15
0.09
0.15




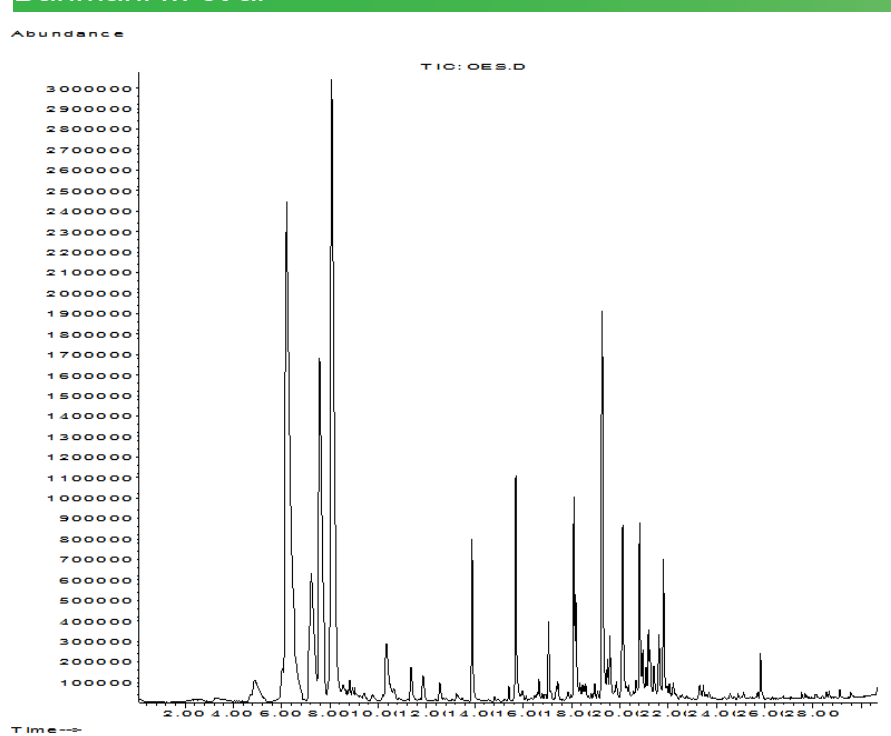

Figure 2. Chromatogram of essential oil of Scrophularia deserti aerial parts using headspace solid-phase microextraction (GC-MC)

\section{Discussion}

S. striata has a variety of uses in traditional medicine, especially in Ilam province, such as relief of pain and inflammation caused by eye and ear infections, relief of pain due to gastrointestinal disorders, treatment of colds, skin wounds and burns, and hemorrhoids [11]. Phytochemical studies have shown that Scrophularia buddleia is a rich source of iridoid glycosides [12]. Another study shows that certain compounds such as alkaloids, glycoside resins, iridoid, cryptophilic acid and flavonoids have been identified and isolated from the Scrophularia plants [13, 14]. A phytochemical study revealed that the active ingredients of $S$. striata included cinnamic acid and three flavonoids, namely quercetin, isorhamnetin, nepitrin, phenyl glycoside and propanoids $[15,16]$. The results of Kerdar et al. (2018) study showed that the essential oil of $S$. striata aerial parts, using hydraulic (water) extraction, was composed of a total of 26 compounds such as n-hexane (16.3\%), caryophyllene oxide (15.36\%), spathulenol (13.1\%), alpha-cadinol (12.35\%), and docosane (6.33\%) [17]. Based on these observations, there is a wide variation in the chemical composition of the essential oil from the same plant in different regions. Caryophyllene oxide, an oxygenated sesquiterpene, is commonly known as a preservative and antifungal agent against dermatophytes [18]. Spathulenol is used as a pesticide, antibacterial and antifungal toxin [19]. Alpha-cadinol has been identified as an antifungal and hepatoprotective agent, as well as a potential therapeutic agent for drug-resistant TB [20,21]. Pasdaran et al. (2012) study showed that in the essential oil of S. amplexicaulis, there was high contents of phenolic compounds derivatives and oxygenated monoterpenes, such as eugenol (53.8\%), eugenol acetate (24.5\%), beta-caryophyllene $(5.7 \%)$. ), and caryophyllene oxide (6.4\%) [22]. The results of the phytochemical study of $S$. oxysepala essential oil revealed that this plant contains the main compounds including phytol (25.3\%), methyl benzyl alcohol (9.3\%), dihydrogenogenol (6.7\%), methyl benzaldehyde (5.3\%). 1) and eugenol (1.3\%) [23]. The main constituents of $S$. frigida essential oil were palmitic acid $(30.49 \%)$, phytol (12.9\%), L-linalool (11.41\%) and hexahydrofarnesyl acetone $(6.65 \%)$ [24], indicating that these compounds vary depending on the location of the plant collection, which can be caused by factors such as environmental conditions and plant genotypes, explaining the differences in the chemical composi- tion of these plants. The major chemical compounds isolated and identified from $S$. striata are cinnamic acid, some flavonoids such as quercetin, isorhamnetin-3-O-rutinoside, nepitrin and a glycoside (octreotide 1). The plant has anti-inflammatory, antibacterial, antioxidant, anticancer, analgesic and neuroprotective as well as wound healing effects [25]. Spathulenol, caryophyllene oxide, linalool, alpha-terpineol, trans-caryophyllene and geraniol alpha-phellandrene, beta-myrcene and trans-caryophyllene can be active ingredients of these two plants that have the above-mentioned therapeutic effects [26-33]. Studies have shown that medicinal plants have both traditional and modern research with the use of stand-alone medicinal and therapeutic effects and their beneficial effects through their active ingredients.

\section{Acknowledgments}

Authors would like to thank the Vice-chancellor for the Research and Technology Deputy of the Ilam University of Medical Sciences and Biotechnology and Medicinal Plants Research Center for funding this study.

\section{Authors' contributions}

$\mathrm{MB}$ reviewed the literature and prepared the first draft of manuscript; NA, MB and $\mathrm{MH}$ reviewed the literature, helped in preparing first draft of manuscript, checked and corrected the grammar. All authors read and approved the final report.

\section{Conflict of interests}

All authors declare that no conflict of interest exist.

\section{Funding/Support}

Biotechnology and Medicinal Plants Research Center, Ilam University of Medical Sciences was supported this research. The research code of this study is A-10-2667-1.

\section{References}

1. Viola S. Plante Medicinale e Velenose de la Flora ltaliana. Milan: Maestri, 1966; 179.

2. Azadbakht M. Classification of medical plants. Tehran: Teimorzadeh Pub. 2000; 7-276-7.

3. Ghahreman A. Colorful flora of Iran.Vol. 24, Farhang Moaser Publications, Tehran 2002.

4. Bahmani M, Ghorbani M, Momtaz H, Bahmani E, Rafieian M. The comparison of the in vitro effects of Scrophularia deserti plant and amphotricin B on Candida albicans. Arak Med Uni J. 2010; 13: 15-21.

5. Ahmed B, Al-Rehaily AJ, Al-Howiriny TA, El-Sayed KA, Ahmad MS. Scropolioside- DR2R and Harpagoside-B: two new iridoid glycosides from Scrophularia deserti and their antidiabetic and antiinflammatory activity. Biolog Pharmac Bulletin. 2003; 26: 462-467.

6. Azadbakht M. Classification of medicinal plants. Timurzadeh Publications, Tehran 1999; 420.

7. Abbasi N, Azizi Jalilian FM. Abdi M. Seifmanesh. The evaluating antimicrobial effect of Scrophularia striata extract on Staphylococcus aureus and Pseudomonas aeruginosa and its comparison with selective effective antibiotics. Med Plants. 2006; 6(1): 10-18.

8. Diaz A, Abad MJ, Fernandez L, Silvan AM, De Santos J and Bermejo B. Phenylpropanoid glycosides from Scrophularia scorodonia: in vitro antiinflammatory activity. Life Sci. 2004; 74(20): 2515-2526. 
9. H. Lord and J. Pawliszyn. Journal of Chromatography A. 2000; 885: 153.

10. Bahmani M. Taherikalani M. Khaksarian, Soroush S, Ashrafi B, Heydari R. Phytochemical Profiles and Antibacterial Activities of Hydroalcoholic Extracts of Origanum vulgare and Hypericum perforatum and Carvacrol and Hypericin as a Promising Anti-Staphylococcus aureus. Mini Rev Med Chem. 2019; 19(11):923-932.

11. Shohani F. Ethnography of Ivan city, Ilam province cultural heritage 2003.

12. Ahmad B, Al-Rehaily AJ, Al-Howiriny TA, El- Sayed KA, Ahmad MS. Scropolioside- D2 and harpagoside-B: two new iridoide glycosides form Scrophularia deserti and their antidiabetic and antiinflammatory activity. Biolog Pharmac Bulletin. 2003; 26(4): 462-467.

13. Tasdemir D, Brun R, Franzblau SG, Sezgin Y, Calis I. Evaluation of antiprotozoal and antimycobacterial activities of the resin glycosides and the other metabolites of Scrophularia cryptophila. Phytomed. 2008; 15(3): 209-215.

14. Shamsa F, Monsef HR, Ghamooshi R, Verdian-Rizi MR. Spectrophotometric determination of total alkaloids in some Iranian medicinal plants. Thai J. Pharmac. Sci. 32 (2008) 1720.

15. Babri SH, Doosti M, Fatehi L, Salari A. The effects of Scrophularia striata extract on anxiety and depression behaviors in adult male mice. J Pharmaceutical Sci. 2012; 18(2): 133140 .

16. Bahrami A. The effectiveness of Scrophularia striata on Newcastle disease. Australian J Basic Appl Sci. 2011; 5(12): 2883-2888.

17. Kerdar T, Moradkhani S, Dastan D. Phytochemical and Biological Studies of Scrophularia striata from Ilam, Jundishapur. J Nat Pharm Prod. 2018; 13(3): 62705.

18. Yang D, Michel L, Chaumont JP, Millet-Clerc J. Use of caryophyllene oxide as an antifungal agent in an in vitro experimental model of onychomycosis. Mycopathol 1999; 148(2): 79-82.

19. Rahman A, Sultana Shanta S, Rashid MA, Parvin T, Afrin S, Khodeza Khatun $\mathrm{M}$, et al. In vitro antibacterial properties of essential oil and organic extracts of Premna integrifolia Linn. Arab J Chem. 2016; 9: 475-9.

20. Ho CL, Liao PC, Wang EI, Su CV. Composition and antifungal activities of the leaf essential oil of Neolitsea parvigemma from Taiwan. Nat Prod Commun. 2011; 6(9): 1357-60.

21. Tung YT, Huang CC, Ho ST, Kuo YH, Lin CC, Lin CT, et al. Bioactive phytochemicals of leaf essential oils of Cinnamomumosmophloeum prevent lipopolysaccharide/D-galactosamine (LPS/D-GalN)-induced acute hepatitis in mice. J Agric Food Chem. 2011; 59(15):8117-23.

22. Pasdaran A, Delazar A, Nazemiyeh H, Nahar L, Sarker SD. Chemical composition, and antibacterial (against Staphylococcus aureus) and free-radical-scavenging activities of the essential oil of Scrophularia amplexicaulis Benth. Records Nat Prod. 2012; 6(4): 350-355.

23. Pasdaran A, Nahar L, Asnaashari S, Sarker SD, Delazar A. Gc-ms analysis, free-radical-scavenging and insecticidal activities of essential oil of scrophularia oxysepala boiss. Pharm Sci. 2013; 19(1): 1.

24. Asgharian P, Heshmati Afshar H, Asnaashari S, Bamdad Moghaddam S, Delazar A. The Seasonal Variations of the Chemical Composition of Essential Oil Obtained From Scrophularia frigida. Jundishapur J Nat Pharm Prod. 2016;
11(1): doi: 10.17795/jjnpp-29742.

25. Tamri P. A mini-review on phytochemistry and pharmacological activities of Scrophularia striata. J Herbmed Pharmacol. 2019; 8(2): 85-89.

26. Valadi A, Nasri S, Abbasi N, Amin GR. Antinociceptive and anti-inflammatory effects of hydroalchoholic extract of Anethum graveolens L. seed. J. Med Plants. 2010; 9(34): 124-130.

27. N. Jabbari, Gheibi P, Eftekhari Z. The therapeutic effects of isolated Eugenol of Syzygium aromaticum . Plant Biotechnol Persa. 2019; 1 (1): 42-44.

28. Moayeri A, Azimi M, Karimi E, Aidy A, Abbasi N. Attenuation of Morphine Withdrawal Syndrome by Prosopis Farcta Extract and Its Bioactive Component Luteolin in Comparison with Clonidine in Rats. Med. Sci. Monitor. Basic Res. 2018; 24(9): 151-158.

29. Eidy A, Ghaneialvar H, Behrooznia F. Herbal plant for heart disease. Plant Biotechnol Persa. 1 (1) (2019) 39-41

30. Bahmani M, Taherikalani M, Khaksarian M, Rafieian-Kopaei M, Ashrafi B, Nazer MR, Soroush S. Abbasi N, Rashidipour M. The synergistic effect of hydroalcoholic extracts of Origanum vulgare, Hypericum perforatum and their active components carvacrol and hypericin against Staphylococcus aureus. Future Sci. OA 2019; 5(3): Article number FSO371.

31. Abbasi N, Khosravi A, Aidy A, Shafiei M. Biphasic response to luteolin in MG-63 osteoblast-like cells under high glucose-induced oxidative stress. Iranian J Med Sci. 2016; 41(2): 118-125.

32. Bahmani F, Kazemeini H, Hoseinzadeh-Chahkandak F, Farkhondeh T, Sedaghat M. Sedation with medicinal plants: A review of medicinal plants with sedative properties in Iranian ethnoblotanical documents. Plant Biotechnol Persa. 2019; 1 (1): 13-24.

33. Karimi E, Abbasi S, Abbasi N. Thymol polymeric nanoparticle synthesis and its effects on the toxicity of high glucose on OEC cells: Involvement of growth factors and integrin-linked kinase. Drug Design, Develop. Ther. 2019; 13: 2513-2532. 